\title{
Devastation and celebration: Digging into culinary roots, race, and place
}

\author{
Review by Yona Sipos*
}

Review of The Cooking Gene: A Journey Through African American Culinary History in the Old South, by Michael W. Twitty. (2017). New York: HarperCollins. Available as hardcover, paperback, and eBook; 464 pages. Publisher's website: https://www.harpercollins.com/9780062379290/the-cooking-gene/

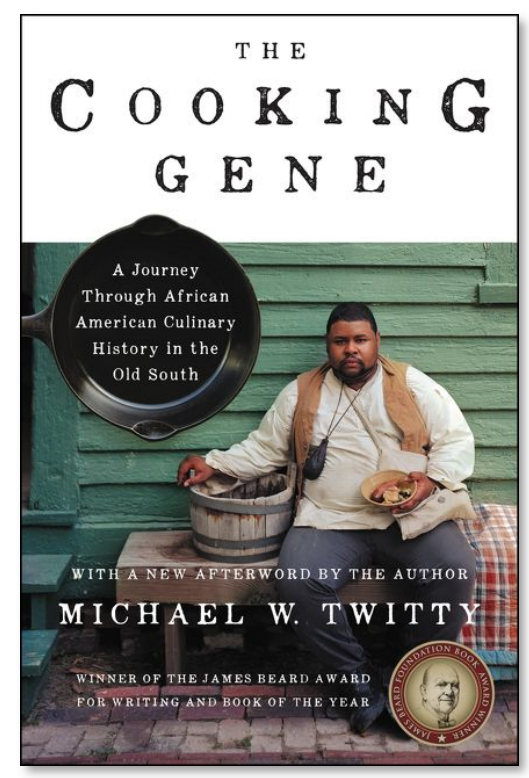

Submitted December 31, 2018 / Published online May 14, 2019

Citation: Sipos, Y. (2019). Devastation and celebration: Digging into culinary roots, race, and place [Book review]. Journal of Agriculture, Food Systems, and Community Development, 9(1), 127-129. https://doi.org/10.5304/jafscd.2019.091.003

Copyright (C) 2019 by the Author. Published by the Lyson Center for Civic Agriculture and Food Systems. Open access under CC-BY license.

$\mathrm{I}$ f you don't already follow Michael Twitty (@koshersoul on Twitter), you are missing out on reflections and extended commentary on his powerful and acclaimed book, The Cooking Gene: $A$ Journey Through African American Culinary History in the Old South. On October 11, 2018, the author tweeted, "The Cooking Gene is a culinary Roots. I wanted other families in African America and the African Atlantic to see ways they could do similar work. I wanted to introduce my country to [its] Black Southern culinary heritage and West Africans to their cousins." He clarifies, "My book is NOT a cookbook. It is a food memoir plus culinary history

* Yona Sipos is a lecturer in the School of Public Health at the University of Washington (UW) in Seattle. She is helping to launch UW's new Food Systems, Nutrition, and Health major in the Nutritional Sciences Program. She can be reached at Nutritional Sciences Program, University of Washington; Raitt Hall 305-J Chelan Lane; Box 353410; Seattle, WA 98195-3410; ysipos@uw.edu. plus genealogical detective story with recipes.... 21 or so."

This concise meta-analysis allows details and treasures of the 425 pages of text, including a new afterword, to fall into sharper relief. Of his winding and comprehensive book, Twitty writes in the author's note, "If it were possible to give a linear, orderly, soup to nuts version of my story or any of my family's without resorting to genre gymnastics, I would have considered it. Instead, I am pleased with the journey as it has revealed itself to me" (p. 427).

The Cooking Gene traverses cultures, continents, regions, and 21 or so recipes to uncover the foodways of today and yesterday, of freedom and bondage, of personal and collective. Twitty unflinchingly reveals the complicated history of Southern cooking alongside identity in America. He guides us along, sometimes by hand and oftentimes galloping far ahead, to share his intimate 
experiences of learning - from his furthest back grandmothers, culinary traditions, genetics-and mapping the foodways as complex, nonlinear, and ongoing. Readers are invited to sit with Mother Corn, King Cotton, and the multihued Queen rice, to spend time in Virginia and the greater Chesapeake, and to travel into the Upper South as pathways to understand the centrality of African experiences on Southern soul food. "Born in the womb of the mother of American slavery," he recounts how soul food exists alongside Southern hospitality, "an extension of teranga, one of the many indigenous concepts of peaceful living based upon hospitable treatment of others ... brought from Senegal and Gambia with the Wolof, Serer, and Fulani" (p. 237). He skillfully wordsmiths the reader to imagine "women negotiating the cooking pots of a new life, using their collective knowledge and experience to make something that would soothe their exile-in tongues 3,500 miles apart with different stories of how they came to be irrevocably enslaved in an alien land. All of the negotiations and conflict ... affected how the food came to be and what we think of as soul or Southern" (p. 163).

Chapter 1 begins as Morning Prayer and an introduction to Twitty cooking on a plantation in his "transformative historical drag" (p. 1). He intersperses stories and context with song lyrics, explaining that "some enslaved cooks timed the cooking by the stanzas of the hymns and spirituals" (p. 3). We meet members of his family and unsung Black culinary heroes; we learn of his pathways to becoming a renowned and independent scholar. He ends the chapter by declaring, "It is not enough to know the past of the people you interpret. You must know your own past" (p. 24). It follows, then, that in the next three chapters, Twitty articulates his own personal becoming and embracing his Blackness, gayness, Southerness, and Jewishness. He extends the intersectional familiensinn (sense of family) feelings with recipes of West African Brisket and Black-Eyed-Pea Hummus. In chapters 5 through 7, Twitty begins to explore African American genealogy in greater depth, starting with names, records, and slave routes. Aiming to find his "white man in the woodpile" (p. 96), he delves into his ancestral stories, finding kinfolk across racial lines. In chapter 8 , he delves into the genetic $0.01 \%$ that makes each of us unique, holding readers close as he journeys into deeply personal familial DNA. After sharing results indicating that he can claim Africa, Europe, and North America each as his own, he concludes that "my food is my flag" (p. 139).

Chapters 9 through 12 recount racism, the twinning of sugarcane, corn, tobacco, and rice agriculture with slavery, and the birth of African American civilization and food traditions. Chapters 13 and 14 focus on African homesteads and personal gardens, truck patches and provision grounds, long pre-dating American victory gardens. Twitty shares insights from D.C.-based nutritionist Tambra Raye Stevenson, who further spells out the connections among food, racism, power, and justice - and the great potential of diet and lifestyle benefits from growing and cooking healthy, nutritious, African foods. Such community gardens can serve to green neighborhoods and connect to traditional knowledge. In chapter 15, Twitty interprets his ancestors' arrival to America in the $16^{\text {th }}$ and $17^{\text {th }}$ centuries, in search of familiar plants and fungi and learning the native ones, with African foodplants such as elephant ear taro and red rice also finding their way to American soil. "We were Americans and Africans all at once-tied to two worlds through a bewildering love of the land" (p. 295).

In chapter 16, Twitty moves to fish, fowl, and other meats of the Old South, merged with African history to forever alter American wilderness. He decries the lack of faces of color-specifically Black faces-populating the contemporary food world, notwithstanding age-old knowledge and experience. Chapters 17 and 18 again delve deep into the persistent pain of slavery linked to the "sordid and greedy nature" (p. 344) of King Cotton. He articulates that the historical "disruption of the Black family, the interruption of an important community-driven ethnic economy, the engendering of a poor diet, an urgent desire to suppress learning and education, and a culture of unrelenting violence" (p. 358) are reverberating rampantly in contemporary American systems.

Chapters 19 through 21 offer a bittersweet summary of food as a "mystical lubricant between the living and the dead" (p. 367). Childhood mem- 
ories are interspersed with a learned appreciation for old ways, visiting and being visited by Twitty's ancestors, both Black and White. Images of "survival, persistence, and memory" (p. 399) culminate alongside gratitude for complexity and meaning. The paperback edition offers a new afterword in which Twitty comes to certain peace while further reflecting on his question of how his destiny has been shaped by the history of Southern food (p. 404) but also why his soul has chosen this journey (p. 425).

The Cooking Gene stands as a testament to the multidimensionality of America. Devastation and celebration are entwined in what can surely be positioned as a living document. Readers are gifted with political, botanical, culinary, and personal histories, so finely detailed as to be exhausting, much as the journeys themselves must have been. But they are also uplifting-perhaps in part because this book has now been written and that in itself is worth commending. As Twitty tweeted (October 11, 2018), “We don't have a lot of culinary narratives from Black males or Black lgbt $\mathrm{ppl}$ or narratives of how food functions in Black families and Black culture." Twitty has masterfully taken oral traditions and, much as his chosen people have done throughout history, has recognized the value of writing them down. He rigorously shares tradition and discovery through his written word, deeply steeped in his own experience and insights. His identity provides the core, and his research, stories, and recipes emerge from that place of knowing, searching, and belonging/notbelonging. Twitty has extended an invitation to his readers to journey with him through the pain, the heat, the words, the wounds, and the path to healing. For academics, practitioners, and students of all stripes, it is well worth the trip. 